\title{
Ground effects induced by the 2012 seismic sequence in Emilia: implications for seismic hazard assessment in the Po Plain
}

\author{
Pio Di Manna ${ }^{1}{ }^{\star}$, Luca Guerrieri $^{1}$, Luigi Piccardi ${ }^{2}$, Eutizio Vittori ${ }^{1}$, Doriano Castaldini ${ }^{3}$, \\ Andrea Berlusconi ${ }^{4}$, Livio Bonadeo ${ }^{4}$, Valerio Comerci ${ }^{1}$, Francesca Ferrario ${ }^{4}$, Roberto Gambillara ${ }^{4}$, \\ Franz Livio ${ }^{4}$, Mauro Lucarini ${ }^{1}$, Alessandro Maria Michetti ${ }^{4}$
}

\author{
${ }^{1}$ ISPRA, Servizio Geologico d'Italia, Roma, Italy \\ ${ }^{2}$ Istituto di Geoscienze e Georisorse, CNR, Firenze, Italy \\ ${ }^{3}$ Università di Modena e Reggio Emilia, Dipartimento di Scienze Chimiche e Geologiche, Modena, Italy \\ ${ }^{4}$ Università dell'Insubria, Dipartimento di Scienza e Alta Tecnologia, Como, Italy
}

\author{
Article history \\ Received July 23, 2012; accepted August 28, 2012. \\ Subject classification: \\ ESI 2007 scale, Coseismic effects, Macroseismic intensity, Seismic hazard, Liquefaction-type phenomena.
}

\section{Introduction}

Since May 16, 2012, a seismic sequence has affected a wide portion of the Emilia Region (northern Italy), chiefly for the Modena and Ferrara Provinces. The first mainshock $\left(\mathrm{M}_{\mathrm{L}}\right.$ 5.9; focal depth, ca. $6 \mathrm{~km}$ ) occurred on May 20, 2012, with the epicenter located a few kilometers north of Finale Emilia. A second main shock $\left(\mathrm{M}_{\mathrm{L}} 5.8\right.$; focal depth, ca. $\left.10 \mathrm{~km}\right)$ occurred on May 29, 2012, about $12 \mathrm{~km}$ west of the first earthquake, with the epicenter near Medolla (Figure 1). The seismic sequence has been characterized by five other $M_{L} \geq 5$ events, and more than 2,300 aftershocks of lower magnitude, until the end July 2012. The distribution of the aftershocks identifies a WNW-ESE-trending zone ca. $40 \mathrm{~km}$ long that is characterized by NNE-SSW nearly pure compression, as indicated by the focal mechanisms [e.g., QRCMT 2012].

This report focuses on the many ground effects that were induced by this seismic sequence, as mainly cracks, liquefaction-type phenomena, and hydrological anomalies. The aim is to provide a complete representation of such effects, to:

- illustrate their type, size and areal distribution;

- identify the zones in the affected area that were most prone to the occurrence of ground effects (i.e., more susceptible to local geological instability in the case of earthquake occurrence);

- carry out an independent assessment of the intensities of the earthquakes through the ESI 2007 intensity scale [Guerrieri and Vittori 2007], which is based only on coseismic effects on the natural environment.

Indeed, the intensity assessment based only on the 'traditional' scales is somewhat problematic for hazard estimates, due to the significant variability of damage to residential buildings and to special and monumental constructions (e.g., churches, towers, bell towers, old farms and barns, industrial sheds), which depends on the geological substratum, the morphological setting, and the construction type. Environmental effects might therefore provide essential information for the characterizing of this sequence, because they only depend on the local geological (s.1.) structure. Moreover, they allow a comparison with historical accounts of earthquake ground effects in the Po Plain.

\section{Geological framework}

The subsurface geology of the epicentral area is marked by the presence of compressional structures of the Apennines that are covered by marine and continental clastic deposits of the Po Plain. Several Quaternary thrusts are indicated by a dense network of seismic lines [e.g., Pieri and Groppi 1981, Cassano et al. 1986, Fantoni and Franciosi 2009]. Stratigraphic, morphological, geodetic and seismic evidence indicate a still-active convergence of northeast-verging Apennines and south-verging southern Alps structures [e.g., Serva 1990, Castiglioni et al. 1997, Boccaletti et al. 2004, Toscani et al. 2009, Boccaletti et al. 2011, Comerci et al. 2012, Michetti et al. 2012, and references therein]. This evidence has been confirmed by earthquake focal mechanisms [Frepoli and Amato 1997] and other stress indicators [Montone et al. 2004].

The geomorphological framework is characterized by a complex drainage and paleo-drainage pattern of the local rivers (the Po, Secchia, Panaro and Reno rivers), which has been strongly influenced by the active tectonics and climate, and by the human modifications introduced in the last centuries. Several localities in the epicentral region are located 


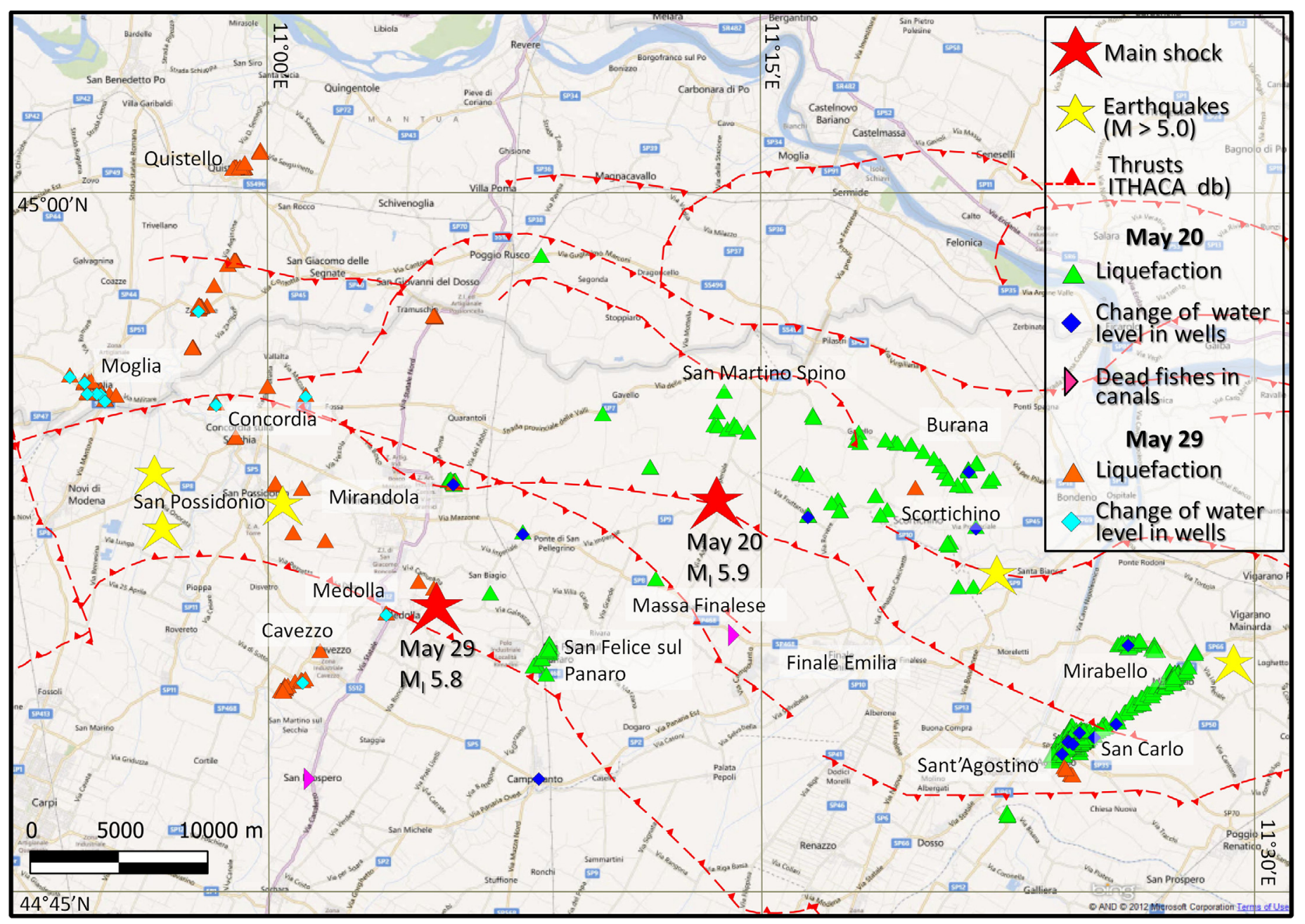

Figure 1. Main shocks of the 2012 Emilia sequence and locations of coseismic effects. Red lines are buried thrusts, many of them judged capable of causing coseismic surface deformation (source: ITHACA).

on the ancient (from Roman times to XVIII century A.D.) abandoned channels of these rivers [Castaldini 1989, Castiglioni et al. 1997, Castiglioni and Pellegrini 2001].

Some active-fault-related folds appear to be very close to the ground surface, and even deform the topographic surface. The Mirandola structure, for example, is a thrust-related fold that is part of the Ferrara Folds, the surface evidence for which is given by the local deflection of the Secchia and Panaro paleoriver beds [Castaldini et al. 1979, Burrato et al. 2003]. Several other thrusts that are believed to be capable of producing surface deformation are shown in the ITHACA database (http: / / sgil isprambiente.it/GMV2/index. html? config=config_sismaMO.xml).

According to the Database of Individual Seismogenic Sources [DISS, 2010], the epicentral zone corresponds to the composite source Novi-Poggio Renatico, constituted by the individual sources Mirandola, Canalazzo di Finale Emilia and Concordia (expected $M_{W}$ 5.9). According to Serva [1990], the above tectonic structures are associated to a potential intensity VIII (Mercalli-Cancani-Sieberg; MCS) earthquake. The available historical evidence (CPTI11) [Rovida et al. 2011] indicates that a seismic sequence comparable to the present one, but slightly east of it, occurred in 1570-1574; more than
2,000 shocks were noted, mainly located near Ferrara [Guidoboni et al. 2007].

\section{Characterization of ground effects}

More than 500 ground effects have been recognized, spread over an area of about $700 \mathrm{~km}^{2}$ (Figures 1,2), as mainly liquefaction-type phenomena, ground ruptures, and hydrogeological anomalies (high water-table fluctuations). About 400 effects were located mainly in the eastern and northern sectors, and were induced by the first mainshock (May 20, 2012), while more than 100 ground effects have been related to the $M_{L} 5.8$ earthquake that occurred on May 29, 2012. Many liquefaction-type phenomena that were triggered by the May 20 , 2012, earthquake were then reactivated by the May 29, 2012, event. The collected data have been progressively added to the EEE Catalog, on-line in the portal (http: / / www.eeecatalog. sinanet.apat.it/emilia/earthquake/index.php).

\subsection{Ground cracks and liquefactions}

Unquestionably, liquefaction-type effects have been the most relevant type of effects induced by these earthquakes on the natural environment. In general, the ejection of sand has occurred along ground cracks, which are often made ev- 


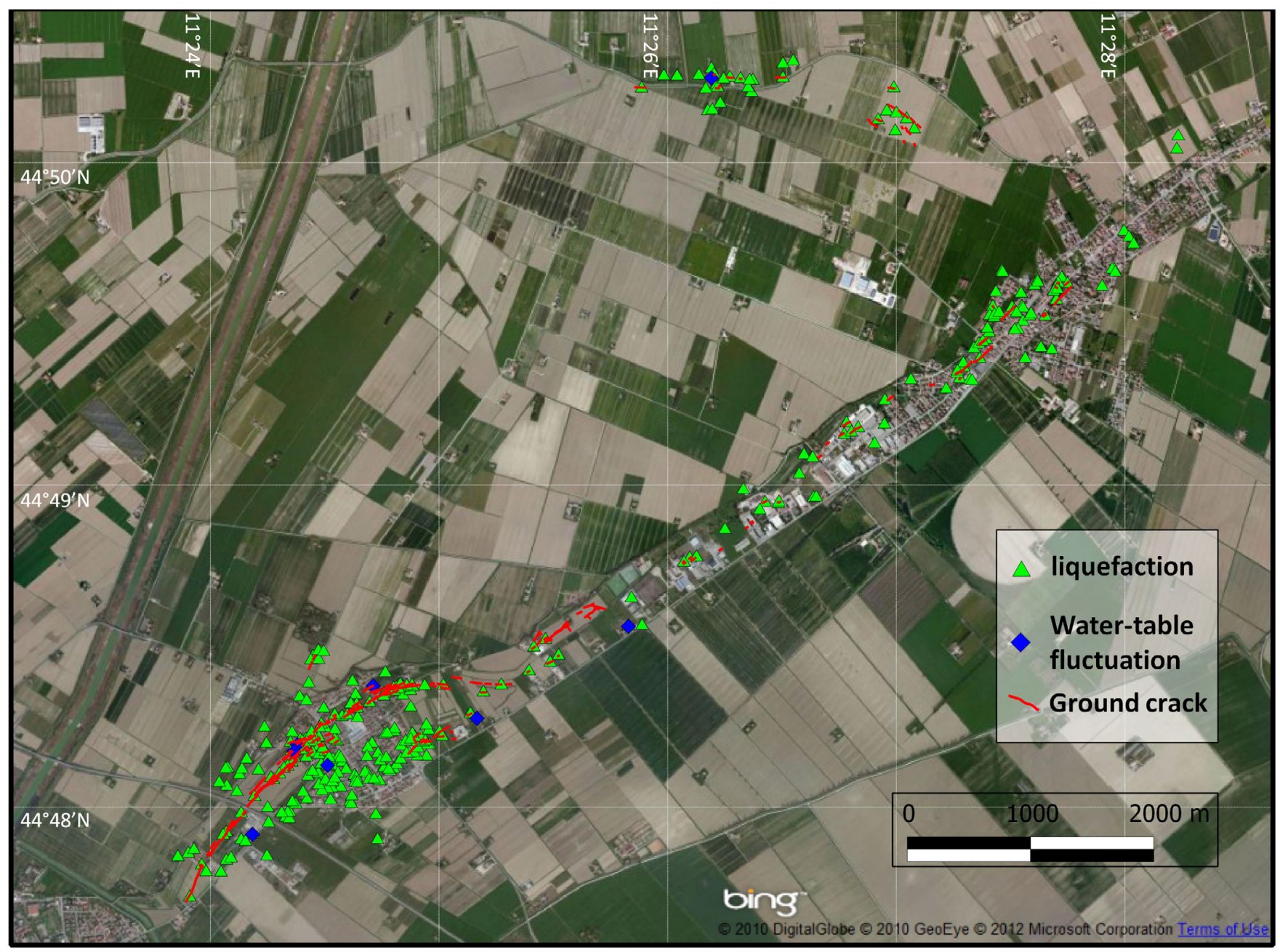

Figure 2. Liquefaction-type phenomena and ground ruptures between Sant'Agostino and Mirabello. These effects were distributed in a NE-SW-trending elongated area located on an ancient paleochannel of the Reno River. They heavily damaged private buildings and industrial plants located above it. Other effects were mapped in a WNW-ESE-trending elongated area located some kilometers northwest of the Mirabello village. These effects were found on a very flat portion of the floodplain, and were not directly linked to any ancient paleoriver.

ident by alignments of emission points.

The zone with the most evident and widespread effects induced by the first mainshock (May 20,2012) is that around San Carlo (Figure 2), a hamlet that is part of the municipality of Sant'Agostino. Here, large ground cracks and widespread liquefaction affected paved roads, buildings and farmland.

The distribution of these effects, as well as the orientation of the ground cracks, clearly identifies a relatively narrow NE-SW-trending elongated area, about $6.5 \mathrm{~km}$ long, running from SW of the Sant'Agostino cemetery to San Carlo (the most damaged center), and up to Mirabello (Figure 2). The ground ruptures were almost continuous, and they damaged all of the constructions above them, especially the houses in San Carlo (which in many cases had to be evacuated) and the industrial plants between San Carlo and Mirabello.

It has to be noted that all of the NE-SW effects between Sant'Agostino and Mirabello were concentrated on the right embankment of an abandoned bed of the Reno River, which was active until the end of the XVIII century, and is mostly characterized by sands, interbedded in finer layers (clays and silts). This local conditions certainly contributed to the oc- currence of the open ground cracks and liquefaction, and significantly enhanced their size. In particular, in San Carlo, the most damaged houses are located on top of the former Reno River embankment, indicating that the topographic effect (lateral spread) had an important role, added to the shaking and the sand liquefaction, in causing the observed damage.

In the area between San Carlo and the cemetery of Sant'Agostino, ground ruptures were very often characterized by significant vertical offset (generally lowering to the NW side) that locally had already reached $50 \mathrm{~cm}$ on the day after the first mainshock (Figure 3a). The opening of cracks was generally of the order of several centimeters, although occasionally they were in excess of half a meter. Repeated surveys have shown a clear post-seismic evolution of ground cracks in terms of increase of throw (up to $60 \mathrm{~cm}$ ) and opening of ground cracks (more than $1 \mathrm{~m}$ ).

As already mentioned, the liquefaction was often associated with ground cracks. In some cases aligned emission cones were clearly identifiable (with cone heights generally lower than $30-40 \mathrm{~cm}$ ). The areal extension of the ejected material (poorly sorted fine grey sand) was very different, ranging 

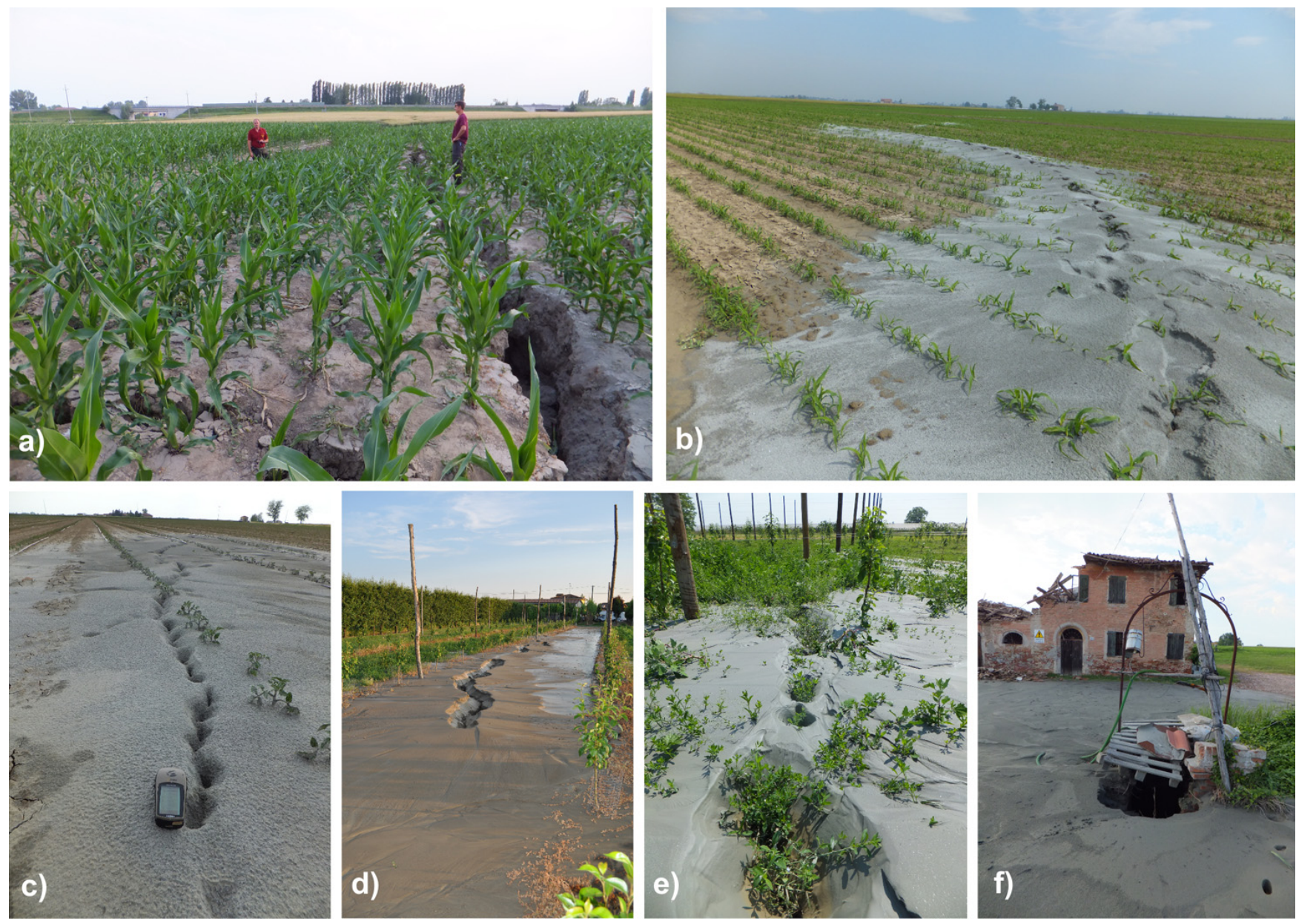

Figure 3. Ground ruptures and associated liquefaction-type phenomena at San Carlo (a), Scortichino (b), Burana (c), Cavezzo (d) and San Possidonio (e). Ejection of copious sand from a water well at San Carlo (f).

from a few square meters up to many hundreds of square meters, depending on the amount of emitted water and the local slope angle. Commonly, the grain size of the sand gets finer, up to a clayey silt, moving upwards in the emission cones.

It is of note that at San Felice sul Panaro at the confluence between the south-north-trending Panaro and the westto-east trending Secchia paleorivers, the most common effect was the ejection of copious sand from water wells. Such effects were roughly aligned in the SW-NE direction, and were particularly frequent in the urban area. Most of these were reactivated by the May 29, 2012, main event.

Nevertheless, liquefaction and ground cracks were also found in other areas of the Po River flood plain that were not related to ancient streams. Among these, aligned WNW-ESE trending ground cracks with associated widespread liquefaction were found northwest of Mirabello. Other similar features were found near Scortichino (Obici locality), Burana and San Martino Spino (Figure 3b, c).

Widespread liquefaction-type effects and ground cracks were produced also by the second mainshock (May 29, 2012). In particular, large ground ruptures with emission of sand were documented mainly in the Cavezzo, San Possidonio, Moglia and Quistello territorial municipalities (Figure 3d, e).

Such phenomena were particularly frequent in Moglia, where, according to eyewitnesses, the occurrence of sand emission has to be related to the two strong aftershocks ( $\mathrm{M} \mathrm{ca}$. 5.1) that occurred on May 29, 2012, at about 1 p.m. At Cavezzo, in a zone that is characterized by a paleochannel of the Secchia River, ground cracks with associated liquefaction-type effects that were arranged in prevalently N50-60E, en-echelon, 20-30$\mathrm{m}$-long segments showed noticeable continuity with a general NE-SW trend for about $1 \mathrm{~km}$. Nevertheless, this alignment is much less evident than that between San Carlo and Mirabello that was related to the May 20, 2012, mainshock.

In some localities (e.g., San Martino Spino, Uccivello [near Cavezzo], Sant'Agostino) the bed of artificial channels showed uplift, bulging and cracks, as an effect of sand injection under the bottom of the channel. This type of phenomenon was observed also at San Carlo, where the floor of the church was strongly deformed. Moreover, at Moglia, a bulge of up to $70 \mathrm{~cm}$ in height and $4 \mathrm{~m}$ in length was observed in a private garden.

Finally, an extensive network of fractures was mapped on the road that runs along the southern bank of the Canale Diversivo, between San Possidonio and Mirandola. The fractures are the effects of the widespread landslides that involved the inner portion of the right bank of the canal for a length of about $1 \mathrm{~km}$. 


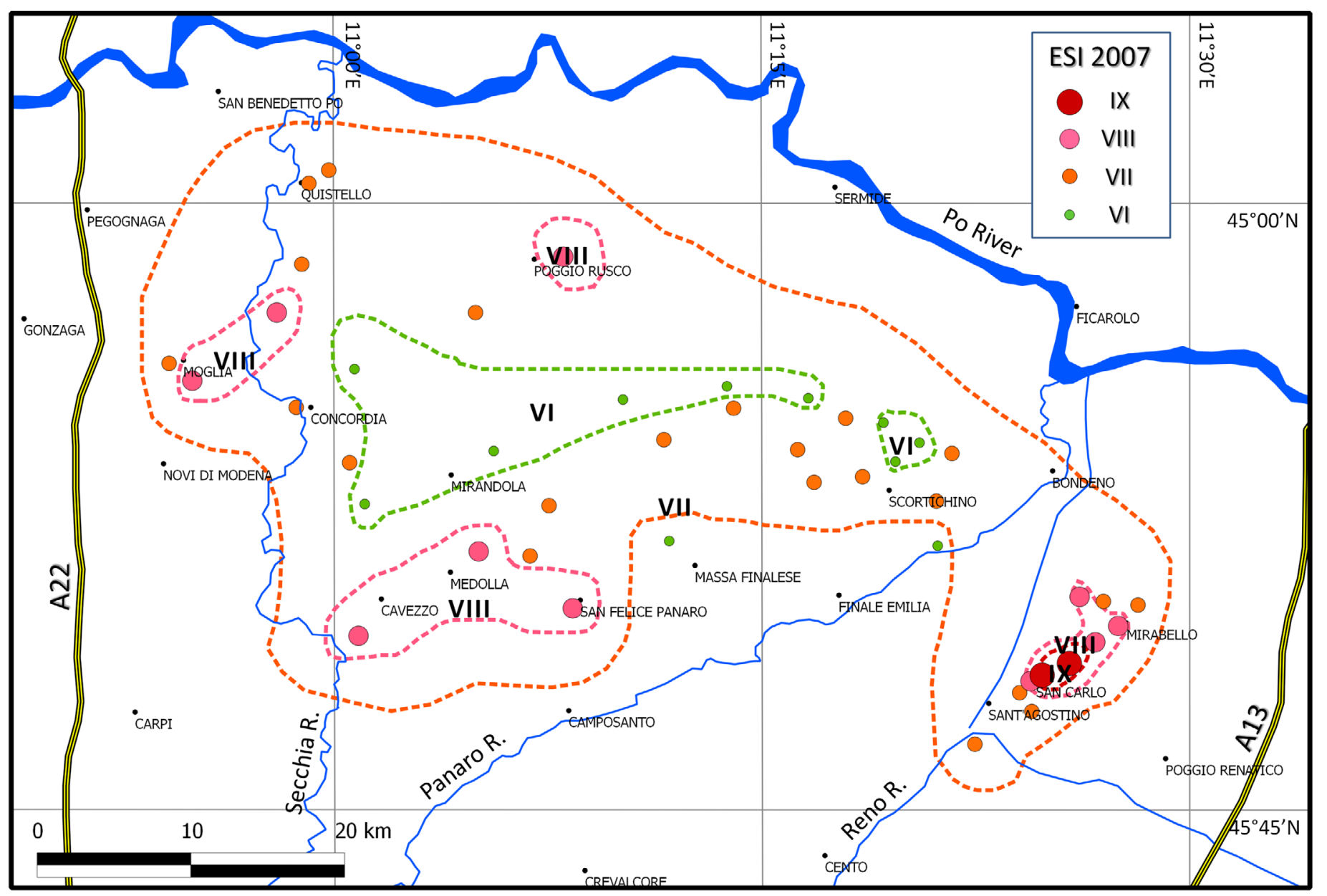

Figure 4. ESI local intensities (based on the characteristics of the surveyed ground effects) and inferred isoseismals.

\subsection{Hydrological anomalies}

In the epicentral area, local people observed a relevant increase in the most superficial water-table level of their water wells (from 3-4 m, up to 8-9 m), generally immediately after the mainshock, but reportedly even hours before in some places. Very often, liquefied sand was ejected out of wells, and sometimes from the well itself, or often following paths on the outer face of the casing, most likely associated with liquefaction (Figure 3f). In some cases, the outflow of water, associated or not with sand ejection, continued for hours after the earthquake. In some instances, notably warm water was emitted from wells. Also, the smell of $\mathrm{H}_{2} \mathrm{~S}$ was sometimes noted, reportedly occurring also many days before the event.

For the May 29, 2012, mainshock, the emission of hot water from ground cracks and water wells was recorded at San Possidonio and Moglia. Furthermore, beginning a few days before the onset of the seismic sequence, an anomalous activity was noted in some mud volcanoes located at the margin of the Modena and Reggio-Emilia Apennines, which are about $40 \mathrm{~km}$ from the epicentral area. In particular, this phenomenon was observed at Regnano, Nirano, Ospitaletto and Puianello. Such mud volcanoes, locally named 'salse', are built by the emission of sodium-chloride water mixed with mud driven to surface by methane (and sometimes liquid hydrocarbons) along ground discontinuities [Capozzi et al. 1994, Martinelli 1999].

\subsection{Other environmental effects}

According to eyewitness accounts, coseismic earthquake lights were observed at San Felice sul Panaro, Cavezzo, Finale Emilia, Quistello and Massa Finalese. In the last of these locations, the time delay of this effect from the first earthquake was $1 \mathrm{~min}$ to $2 \mathrm{~min}$. This kind of phenomena were recorded in the occasion of the seismic swarm of December 23, 2008 (mainshock, $M_{L}$ 5.1) in the Parma Apennines [Straser 2009]. Furthermore, the large amount of dead fish, due to asphyxia (at least 30 quintals in total in the epicentral area), appears to be related to some peculiar environmental effect from the subsoil, most likely as emissions of gases and/ or hot water; e.g., putrefaction gases might have been released from near-surface swamp beds very rich in organic matter.

\subsection{ESI intensity assessment}

Although our surveys are probably still incomplete, the information that has been gained from them is certainly representative of the most significant ground effects, and therefore adequate to define a preliminary macroseismic intensity field (Figure 4) based on the ESI 2007 scale [Guerrieri and Vittori 2007]. This is a recently developed seismic intensity scale that is entirely based on the characteristics and size of earthquake-induced environmental effects, and it has been tested with several modern historical and paleoearthquakes 
[e.g., Reicherter et al. 2009, and references therein, Lalinde and Sanchez 2007, Lekkas 2010].

The total area where ground effects occurred is in the order of $300 \mathrm{~km}^{2}$ to $400 \mathrm{~km}^{2}$ for each event. This indicates that the ESI epicentral intensity of the two mainshocks is VIII. Furthermore, ESI local intensity values in excess of VIII, possibly reaching the IX degree, were recorded in two localities (San Carlo and Mirabello), based on the size and length of the ground ruptures and the areal distribution of the liquefaction, which shows the specific vulnerability of the natural environment at a local scale.

Comparing the ESI local intensity values with the macroseismic intensity evaluations (MCS) [Galli et al. 2012] based on the pattern of damage to buildings, it is evident that: (i) the epicentral intensity evaluations are comparable; and (ii) where available, environmental effects can be a better tool for local intensity assessment, as they are independent of the type of construction, but are governed directly by the true geological (s.l.) site conditions.

For these reasons, a macroseismic intensity field that integrates ESI and MCS intensity evaluations represents a better tool to characterize this event in the framework of seismic-hazard assessment of the Po Plain area. In this perspective, the Emilia 2012 event should be regarded as a relatively minor event compared to the 'reference earthquake' of the Po Plain, which, as demonstrated by the 1117 Verona and 1222 Brescia earthquakes [e.g., Serva 1990, Michetti et al. 2012], should be expected to be characterized by an intensity $\mathrm{I}_{0}$ of IX to X degrees, in either the macroseismic scales or those of the ESI 2007.

\section{Final remarks}

The most common type of ground effect that occurred in the epicentral area of the Emilia 2012 seismic sequence was the liquefaction-type phenomena, which were characterized by the ejection of sand from ground fractures and wells. These phenomena were not randomly distributed, but appear to be concentrated along alignments that can be followed even for kilometers. This is the case of the impressive set of SW-NE fractures, which were widely connected to lateral spread between the cemetery of Sant'Agostino and Mirabello. These caused extensive damage to houses, infrastructure and industrial plants. This alignment followed the right margin of an abandoned and suspended river bed, relative to a former course of the Reno River between San Carlo and Mirabello. Thus, all of the effects along this alignment can be interpreted as secondary effects driven not only by the local stratigraphic characteristics of the subsoil (sands interbedded by clays and silts), but also by the local recent geomorphological evolution, dominated by a complex network of paleo-drainage and abandoned streams. A less-evident alignment is observable also in the distribution of the effects induced by the May 29, 2012, event near Cavezzo, which was related to an ancient bed of the Secchia River.

Other alignments that were roughly oriented east-west were identified in completely flat areas of the Po flood plain (e.g., west of Mirabello and west of Bondeno). These alignments cannot be directly explained with the local influence of paleo-drainage. Instead, their origin might be linked to the presence of east-west-trending tectonic discontinuities that characterize the very shallow subsoil of the area. The coseismic reactivation of these tectonic structures might have facilitated the occurrence of sand ejection up to the surface.

The distribution of ground effects is suggestive of two events of intensity VIII on the ESI 2007 scale, even if the maximum intensity might have been even higher (IX?) in San Carlo and Mirabello. Nevertheless, the estimated intensity of the Emilia 2012 earthquakes is slightly less than that recorded in the Po Plain area in historical times ( $\mathrm{I}_{0} \mathrm{IX}$ to $\mathrm{X}$ ), and therefore should not be considered the 'reference earthquake' for this area.

Acknowledgements. The Authors wish to thank the colleagues of the EMERGEO Working Group, CNR - IAMC, the Department of Civil Protection and the Geological, Seismic and Soil Survey of Regione Emilia-Romagna for their collaboration in geological data exchange and field discussions.

\section{References}

Boccaletti, M., M. Bonini, G. Corti, P. Gasperini, L. Martelli, L. Piccardi, P. Severi and G. Vannucci (2004). Carta sismotettonica della Regione Emili-Romagna, Scala 1:250000, S.EL.CA., Firenze.

Boccaletti, M., G. Corti and L. Martelli (2011). Recent and active tectonics of the external zone of the northern Apennines (Italy), Int. J. Earth Sci. 100, 1331-1348; doi: 10.1007/ s00531-010-0545-y.

Burrato, P., F. Ciucci and G. Valensise (2003). An inventory of river anomalies in the Po Plain, northern Italy: evidence for active blind thrust faulting, Annals of Geophysics, 46 (5), 865-882.

Capozzi, R., V. Menato and E. Rabbi (1994). Manifestazioni superficiali di fluidi ed evoluzione tettonica recente del margine Appenninico Emiliano-Romagnolo: indagine preliminare, Atti Ticinensi di Scienze della Terra, serie speciale, 1, 247-254.

Cassano, E., L. Anelli, R. Fichera and V. Cappelli (1986). Pianura Padana. Interpretazione integrata di dati geofisici e geologici, Proc. $73^{\circ}$ Meeting Società Geologica Italiana (Rome, September 29 - October 4 1986), 27 pp.

Castaldini, D. (1989). Geomorfologia della bassa Pianura Padana modenese e dei territori limitrofi, In: Mirandola e le valli, immagini e documenti, Tipografia Golinelli, Mirandola, 25-37.

Castaldini, D., G. Gasperi, M. Panizza and M. Pellegrini (1979). Neotettonica dei Fogli 74 (Reggio nell'Emilia) (p.p.) e 75 (Mirandola) nell'intervallo da 18.000 B.P. all' 
Attuale (interv. V), CNR Progetto Finalizzato Geodinamica, Nuovi contributi alla realizzazione della Carta Neotettonica di Italia, Pubblicazione 251, 317-332.

Castiglioni, G.B., et al. (1997). Carta geomorfologica della Pia-nura Padana alla scala 1:250.000, S.EL.CA., Firenze.

Castiglioni, G.B., and G.B. Pellegrini (2001). Note illustrative della carta geomorfologica della Pianura Padana/ Illustrative notes of the geomorphological map of the Po Plain, Supplement to Geogr. Fis. Din. Quat., IV.

Comerci, V., A.M. Blumetti, P. Di Manna, D. Fiorenza, L. Guerrieri, M. Lucarini, L. Serva and E. Vittori (2012). Il Progetto ITHACA e le Faglie Capaci della Pianura Padana, Ingegneria Sismica, Special volume "Rischio Sismico in Pianura Padana", in press.

DISS Working Group (2010). Database of Individual Seismogenic Sources (DISS), version 3.1.1: A compilation of potential sources for earthquakes larger than M 5.5 in Italy and the surrounding areas, Istituto Nazionale di Geofisica e Vulcanologia; http: / / diss.rm.ingv.it/diss /

Fantoni, R., and R. Franciosi (2009). Mesozoic extension and Cenozoic compression in the Po Plain and the Adriatic foreland, Rendiconti online Soc. Geol. It., 9, 28-31.

Frepoli, A., and A. Amato (1997). Contemporaneous extension and compression in the northern Apennines from earthquake fault-plane solutions, Geophys. J. Int., 129, 368-388; doi:10.1111/j.1365-246X.1997.tb01589.x.

Galli, P., S. Castenetto and E. Peronace (2012). Terremoto dell'Emilia, Maggio 2012. Rilievo macrosismico speditivo, Dipartimento della Protezione Civile Nazionale, Roma, 26 pp.; http: / www.protezionecivile.gov.it/ resources/ cms / documents / TerremotoEmiliaMCS.pdf

Guidoboni, E., G. Ferrari, D. Mariotti, A. Comastri, G. Tarabusi and G. Valensise (2007). Catalogue of Strong Earthquakes in Italy from 461 B.C. to 1997 and in the Mediterranean Area, from 760 B.C. to 1500, An Advanced Laboratory of Historical Seismology; http: / / storing.ingv. it / cfti4med/

Guerrieri, L., and E. Vittori, eds. (2007). Intensity Scale ESI 2007, Memorie Descrittive Carta Geologica. d'Italia, vol. 74, Servizio Geologico d'Italia - Dipartimento Difesa del Suolo, APAT, Roma, 53 pp.

Lalinde, C.P., and J.A. Sanchez (2007). Earthquake and environmental effects in Colombia in the last 35 years, INQUA Scale Project, B. Seismol. Soc. Am., 97, 646-654.

Lekkas, E.L. (2010). The 12 May 2008 Mw 7.9 Wenchuan, China, earthquake: macroseismic intensity assessment using the EMS-98 and ESI 2007 scales and their correlation with the geological structure, B. Seismol. Soc. Am., 100, 2791-2804; doi:10.1785/0120090244.

Martinelli, G. (1999). Mud volcanoes of Italy: a review, Giornale di geologia, 61, 107-113.

Michetti, A.M., F. Giardina, F. Livio, K. Mueller, L. Serva, G. Sileo, E. Vittori, R. Devoti, F. Riguzzi, C. Carcano,
S. Rogledi, L. Bonadeo, F. Brunamonte and G. Fioraso (2012). Active compressional tectonics, Quaternary capable faults and the seismic landscape of the Po Plain (northern Italy), Annals of Geophysics, in press; doi:10.44 01 / ag-5462.

Montone, P., M.T. Mariucci, S. Pondrelli and A. Amato (2004). An improved stress map for Italy and surrounding regions (central Mediterranean), J. Geophys. Res., 109, B10410, 22 pp.; doi:10.1029/2003JB002703.

Pieri, M., and G. Groppi (1981). Subsurface geological structure of the Po Plain (Italy), C.N.R., Progetto Finalizzato Geodinamica, Pubblicazione 414, 1-13.

QRCMT (2012). Quick Regional Centroid Moment Tensor, INGV-Bologna; http: / / autorcmt.bo.ingv.it/ quicks.html

Reicherter, K., A.M. Michetti and P.G. Silva Barroso (2009). Palaeoseismology: historical and prehistorical records of earthquake ground effects for seismic hazard assessment - introduction; In: K. Reicherter, A.M. Michetti and P.G. Silva (eds.), Palaeoseismology: Historical and Prehistorical Records of Earthquake Ground Effects for Seismic Hazard Assessment, The Geological Society, London, Special Publications, 316, 1-10; doi:10.1144/SP316.9 0305$8719 / 09 /$.

Rovida, A., R. Camassi, P. Gasperini and M. Stucchi, eds. (2011). CPTI11, the 2011 version of the Parametric Catalogue of Italian Earthquakes, Milano/Bologna; http: / / emidius.mi.ingv.it/CPTI

Serva, L. (1990). Il ruolo delle Scienze della Terra nelle analisi di sicurezza di un sito per alcune tipologie di impianti industriali: il terremoto di riferimento per il sito di Viadana (Mn), B. Soc. Geol. Ital., 109, 375-411.

Straser, V. (2009). A 'Jackpot' for the Forecast of Earthquakes. The Seismic Swarm in the North-Western Apennines, December 2008, New Concepts In Global Tectonics Newsletter, No. 51, 4-13.

Toscani, G., P. Burrato, D. Di Bucci, S. Seno and G. Valensise (2009). Plio-Quaternary tectonic evolution of the northern Apennines thrust fronts (Bologna-Ferrara section, Italy): seismotectonic implications, It. J. Geosci. (B. Soc. Geol. Ital.), 128, 605-613; doi:10.3301.IJG2009.128.2.605.

\footnotetext{
${ }^{\star}$ Corresponding author: Pio Di Manna, ISPRA, Servizio Geologico d'Italia, Roma, Italy; email: pio.dimanna@isprambiente.it.

C 2012 by the Istituto Nazionale di Geofisica e Vulcanologia. All rights reserved.
} 